\title{
AUTO-RETRATO ROUBADO: ROCHELLI COSTI
}

Maria Luiza Calim de Carvalho Costa

FAAC-UNESP/Bauru

"Não se conhece nem as coisas nem as
pessoas, se reconhece. Nenhuma pessoa
permanece fixa... É necessário admitir a
ação do espectador sobre a pintura
como se admite a ação do pintor sobre
a coisa imaginada, a ação do que olha
sobre o que olha..."
Pierre Francastel

Duas fotografias, "50 Horas", da fotógrafa Rochelle Costi; dois autoretratos, em busca do leitor. Auto-retrato em busca de si mesma. Suas fotos são construídas pela repetição de sua imagem nua deitada como se estivesse posando para um pintor. Dois textos estéticos, imagéticos, que propõem ao leitor, possibilidades de múltiplas leituras. Cabe ao leitor desvendar essa trama de significantes e fazer emergir dela o significado. Os retratos tratam do gênero, da representação do feminino, da passagem do tempo, da transformação que o tempo impõe...

Em nossa pesquisa, vinculada ao projeto de extensão que coordenamos - Pólo Arte na Escola-educação continuada para profissionais da rede pública estadual e municipal da região de Bauru- e, principalmente, ao Grupo de Pesquisa Leitura: Texto e Imagem (CNPq), tratamos da questão da leitura, a partir do leitor e sua relação com o texto não-verbal.

Muitos autores buscaram caminhos metodológicos para ler um texto imagético, metodologias que buscam dar conta de tarefa tão complexa. Acreditamos que métodos podem auxiliar, criar possibilidades para o leitor, mas, todavia, o próprio texto oferece os caminhos para o leitor, o texto estético baliza o leitor no ir e vir do ato de leitura. O próprio texto orienta o leitor em seu trajeto, claro que o leitor é balizado, também, por outros fatores como pelo seu repertório, por suas lentes ideológicas, pelo olhar social do tempo e lugar em que está inserido, etc.

\section{Leitura: o olhar em busca de sentido}

Entendemos que o leitor precisa desconstruir o texto, para, a partir da relação entre cada elemento, constituir a sua interpretação. Não se trata de 
encontrar um centro, como a postular a existência de uma significação original e central, de relacionar a obra com uma intenção, uma origem que garanta a unidade de sentido, ou seja, transformar o que é diverso em único. Trata-se, sim, de uma "leitura disseminadora e centrífuga", cuja origem é o desconstrutivismo derridiano. "Já que todo signo se constitui a partir das diferenças que o opõem aos outros; a linguagem não tem, portanto, nem centro, nem início, não existe local original. Assim, é impossível conceber ler um livro como um todo: os sentidos de um texto inútil querer fixá-los - se fazem e se desfazem sem parar" (JOUVE,2002,p.98).

A ambigüidade da linguagem poética dá ao leitor um papel ativo na recepção: transforma-o em co-criador, produtor de sentido. Há, para o leitor/espectador, um aprendizado a ser desenvolvido: aprender a olhar. Alfredo Bosi ${ }^{1}$ distingue olho de olhar, levantando na etimologia de palavras em várias línguas como oeil e regarder em francês, ojo e mirada em espanhol, eye look em inglês, a percepção, no corpo dos idiomas, de que o olho é órgão receptor externo e olhar é o "movimento interno do ser que se põe em busca de informações e de significações".

O processo de conhecimento, na comunicação artística, advém das relações significativas que o leitor/espectador realiza no ato de fruição e apreensão da obra. É a partir da percepção das linhas, texturas, cores, etc; e das relações significativas que o leitor traça, por meio da sensibilidade, imaginação, intelecto, que o significado se constrói.

O objeto se situa em rede na qual o leitor constrói o significado de acordo com o tipo de comunicação, freqüência e associação simbólica que faz. O leitor elege as conexões de acordo com o juízo perceptivo e desenvolve a capacidade de ampliar a rede, quanto mais exercita a leitura e as possibilidades associativas.

Apoiamos-nos, como ênfase teórica, na Estética da Recepção e do Efeito - Hans Robert Jauss e Wolfgang Iser- , teoria da literatura da Escola de Constanza, que surge da confluência da Poética e da Hermenêutica. A teoria que é inaugurada por Jauss no início da década de 60 do século XX, postula a idéia de que o texto é atualizado pelo leitor ou seja é o processo de recepção e efeito de uma obra que instaura o significado. A obra é, então, mutável, as leituras diferem em cada tempo e lugar em que são lidas.

${ }^{1}$ BOSI, Alfredo. Fenomenologia do Olhar. In NOVAIS, A. (org) O Olhar. São Paulo: Companhia das Letras, 1995. 
Entretanto, Jauss, esclarece que não é necessário um mergulho na subjetividade do leitor para encontrar o tipo de recepção de uma obra em um determinado tempo histórico, porque cada obra, no momento de sua produção traz o olhar do seu tempo. Jauss determina, portanto, um leitor virtual que tem um saber construído- a compreensão prévia de gênero, da forma e da temática de obras anteriormente lidas-., saber esse, imanente na obra, pois foi produzida com os códigos vigentes do tempo da produção. Ou seja, a obra predetermina a recepção, nas palavras de Jauss evoca o horizonte de expectativas e as regras do jogo. Cada leitor pode reagir, conforme seu repertório, individualmente ao texto, contudo o ato de leitura é uma performance social.

O leitor deve perceber a questão do tempo/espaço entre produção e leitura. Jauss (1980), diz que para se levantar que tipo de compreensão, de interpretação e de aplicação é própria a um texto de caráter estético, é preciso reconstruir o contexto histórico, da intenção primitiva do autor ou da obra. O autor diz que convém destacar os horizontes de uma primeira leitura - a atividade da percepção estética- de uma segunda leitura que constitui uma exegese retrospectiva e acrescentar uma terceira leitura histórica, para aparecer o texto no horizonte de sua alteridade e de sua semelhança em relação à nossa experiência atual. $\mathrm{O}$ valor da obra, segundo Jauss, decorre da percepção estética que a obra é capaz de suscitar.

A interação texto-leitor, abordada por Iser (1979), requer do leitor atividades imaginativas e perceptivas gerando o efeito estético. Atividades imaginativas não quer dizer que cada leitor possa tirar a conclusão que desejar, pois, segundo Iser, a organização de referências, a estrutura do texto, enquanto instrução, orienta a leitura. Todo texto tem uma intenção comunicativa, foi escrito para ser lido, quanto à recepção Iser alerta: “o leitor contudo, nunca retirará do texto a certeza explícita de que sua compreensão é justa" (ISER, 1979,p.87).

\section{O retrato de Rocheli Costi - o leitor frente a obra: o efeito estético}

Na primeira foto, com imagem mais distante, vinte e sete repetições, como num fotograma, intercalam-se uma presença e uma ausência. Fundo azul, uma espécie de maca azul com um lençol branco, com um cubo de madeira azul à frente, chão rústico, compõem o cenário que aparenta precariedade. Sobre um lençol branco, em dezoito das vinte e sete repetições, está a fotógrafa nua, recostada em duas almofadas ou travesseiros, aparentemente, 
dormindo. Presença e ausência, uma afirmação e uma negação, um é mas não é...

O leitor frente ao auto-retrato de Rocheli Costi, é tragado pelo estranhamento que a imagem apresenta. O que faz a fotógrafa se autoretratar nua como se estivesse posando para um pintor? Por que essa ausência em alguns fotogramas? Que afirmação de si mesma deseja evidenciar nesse auto-retrato?

Victor Chklóvski, teórico da escola formalista russa, propõe a concepção do efeito de estranheza, o qual oferece ao leitor um elemento novo, inusitado e por isso estranho. O estranhamento leva o receptor a ver de um outro modo, desviando do clichê, e oferecendo um reconhecimento, ou seja um conhecer outra vez, ao invés da identificação automática. Uma percepção mais apurada é requisitada do leitor frente a um objeto extraído do seu habitual contexto, e transposto de modo novo, oferecendo uma faceta insólita. (FERRARA,1986)

$\mathrm{Na}$ segunda foto, a objetiva se aproxima, vinte e sete repetições, agora fragmentadas as imagens são ora recortes de fotos, ora de pinturas. A repetição do retrato, segundo Barthes, dá acesso a uma temporalidade diferente e leva a uma alteração da pessoa tanto na dimensão moral, psicológica quanto histórica. Se o retrato com pose, tanto diante do cavalete quanto da câmara fotográfica, é uma afirmação de uma essência do indivíduo, ao repetir, a própria imagem, Costi oferece a sua imagem através de um movimento, como em um fotograma, onde o tempo, trans-forma, e ao invés da afirmação fica uma indagação de si mesma. Diante dos autoretratos de Costi, o leitor é seduzido a decifrar o enigma da artista.

\section{A ancoragem do título e o contexto da produção}

O título da obra enuncia um trajeto a percorrer, ancora o leitor a deriva no mar de significações. Entretanto, "50 horas- Auto-Retrato Roubado", não parece esclarecedor... Para encontrar o fio e desenrolar a trama é necessária uma pesquisa sobre o contexto de produção da obra. Durante estadia em Londres, Rochelli Costi, posou como modelo nu. A cada 45 minutos, paralisada, em pose, descansava 15 minutos. Como artista que é, não se contentou em ser apenas modelo, levou sua câmera fotográfica, posicionou-a em tripé e fotografou suas poses e também as pinturas que os 
alunos realizaram dela. Com as fotos, montou quatro painéis ${ }^{2}$ de 1,20x120 $\mathrm{cm}$ cada, com fotomontagens. Quanto ao título, 50 horas, é número de horas que posou, e auto-retrato roubado carrega uma ambigüidade...

Rochelli Costi escreveu um texto para acompanhar a obra:

50 horas

Auto-retrato roubado

50 horas posando para uma classe de pintura. Dói-me o corpo e a dificuldade de encontrar um sentido, além do financeiro, para estar fazendo isso. Até que percebo o grande privilégio de ser o objeto. De usar seu ponto de vista, vivendo a cena pelo avesso. Através da contra-luz, vejo os efeitos que atingem minha superfície. Nos intervalos da aula, vingo-me da imobilidade forçada, repetindo a pose para fotografar a mim mesma.

Fotografar se torna assim o gesto capaz de ilustrar o estreito limite entre o óbvio e o absurdo, limite que nos deparamos mais do que nos damos conta.

Atividade e passividade dependem apenas como ocupar o espaço.

Londres, janeiro de 1992.

\section{As relações intertextuais}

Apesar da organização diacrônica da História da Arte, é a simultaneidade que organiza a dinâmica do jogo das intertextualidades no ato de leitura. A intertextualidade está presente quando de um texto emerge outro, ou outros textos, de forma implícita ou explícita, propiciando ao leitor uma rede com imbricações que ele tem de resolver com um trabalho de assimilação e transformação. O grau de explicitação da intertextualidade depende da forma em que transparece no texto e também da capacidade do leitor, através de seu repertório, de encontrar as relações e articulá-las. A citação é a forma mais direta e evidente de intertextualidade, mas pressupõe uma competência na decifração da linguagem por parte do leitor. Ele precisa conhecer o texto citado e seu contexto, para identificar no bojo do novo contexto as relações que o autor propõe. Mas as relações intertextuais podem não ser tão evidentes como no caso das citações, e requerer do leitor uma maior sensibilidade e conhecimento para identificá-las. O leitor ao deparar-se com o já-visto exposto de modo inusitado é levado à

2 A obra pertence ao acervo do MAM - Museu de Arte Moderna de São Paulo. Os quatros painéis foram idealizados para serem expostos em uma parede, por sua dimensão propõe ao leitor que é uma obra para ser lida por um corpo em movimento. A proposição de leitura de duas obras, rompe com a integralidade do discurso da obra, entretanto, entendemos que cada um dos painéis que compõem a obra tem uma certa autonomia. Fragmentação e unidade são matéria de que trata a obra, assim como presença e ausência. 
reflexão, aquela repetição, recortada, colada, sobreposta ou superposta, suscita um novo olhar, adquire outro sentido, amplia os horizontes de leitura. Desse modo, a intertextualidade propõe ao leitor um olhar crítico e por isso é transformadora.

Laurent Jenny (1979) trata também no mesmo texto sobre a questão da ideologia intertextual. Já que as determinações ideológicas são inerentes à linguagem, quando um fragmento intertextual é encontrado pelo leitor, ele pede um olhar atento a uma função crítica tanto sobre a forma quanto sobre o conteúdo. As funções que o intertexto adquire, nesse sentido, são, então explanados:

A análise do trabalho intertextual mostra bem que a pura repetição não existe, ou, por outras palavras, que esse trabalho exerce uma função crítica sobre a forma. ...Repetir para delimitar, para fechar num outro discurso, conseqüentemente mais poderoso. Falar para obliterar. Ou então, pacientemente, negar para ultrapassar... Ou então reificá-lo, torná-lo objeto de metalinguagem. Abre-se então o campo de uma palavra, nova, nascida das brechas do velho discurso, e solitária daquele. Quer queiram quer não, esses velhos discursos injetam toda a força de estereótipos na palavra que os contradiz, dinamizam-na. A intertextualidade fá-los assim financiar a sua própria subversão (JENNY, Laurent,1979, p.44-45).

Jenny fala da intertextualidade como "máquina perturbadora", aquela que não deixa o sentido sossegar, que evita o "triunfo do clichê" em prol de um trabalho de transformação. O deslocamento do fragmento intertextual para uma nova contextualização, oferece abertura da estrutura textual para uma potencialidade de múltipla significação. "É a recusa do ponto final que poderia fechar o sentido e paralisar a forma" (JENNY,1979,p.46).

Ao se retratar posando para um pintor, a fotógrafa retira seu autoretrato do âmbito particular para trazer a baila a representação da mulher na tradição pictórica, remetendo a pinturas como Vênus de Ticiano, Maja Desnuda de Goya, Olympia de Manet. A Vênus é a idealização da mulher, já a Maja e a Olympia são mulheres de carne e osso que olham o espectador de frente. Resgata as representações das Vênus de Ticiano, de Velásquez, atravessa a desconstrução da figura feminina, fragmenta-se como uma mulher picassiana, deforma-se em um grito mudo expressionista.

Além da intertextualidade com a pintura, Costi dialoga também com o cinema, ao gerar uma sensação de passagem do tempo com a repetição imagens, como se fossem fotogramas. Na primeira foto, com imagem mais distante, vinte e sete repetições, intercalam-se uma presença e uma ausência. $\mathrm{Na}$ segunda foto, a objetiva se aproxima, vinte e sete 
repetições, agora fragmentadas as imagens são ora recortes de fotos, ora de pinturas.

\section{O tempo da produção e o da recepção: o recorte sincrônico do tempo histórico}

O olhar do artista possibilita, ao leitor de sua obra, uma nova perspectiva de olhar. O encontro desses olhares - do artista e do leitor- sobre um mesmo objeto, ou tema, já se transforma em um diálogo que atravessa o tempo. Diante de uma obra, o leitor-espectador encontra-se com o seu produtor e sua visão de mundo, encontra-se também, com o tempo da produção da obra e com o universo sócio-político-cultural desse tempo-local, o que faz da leitura de uma obra de arte uma viagem ao mesmo tempo interior quando em contato com o modo de ver do artista, e, uma viagem geohistórica - quando em contato com o tempo-lugar de produção da obra. Nessa viagem, o leitor não se desvencilha do olhar de seu tempo, o que faz gerar um diálogo entre dois tempos: o da produção da obra e o do leitor. $\mathrm{O}$ tempo que me refiro aqui, é o tempo/espaço sócio-político-cultural em que se situa a produção e a recepção.

$\mathrm{O}$ ato de leitura de uma obra de arte, leva então a um processo de busca de significados, implícitos ou explícitos, marcados pelo tempo e espaço em que foram produzidos, assim como, é claro, pelo o olhar do artista e sua visão de mundo. Esses significados entram em diálogo com o tempo e espaço em que se encontra o leitor e sua visão de mundo contemporânea. Esses diálogos, de acordo com o repertório do leitor, vão se constituir em redes com conexões, num encadeamento de relações que só se esgotam quando o leitor se der por satisfeito com o significado. Ou seja, quanto mais relações intertextuais o leitor for capaz de fazer, mais complexa a trama da rede, que tende ao infinito em suas relações.

\section{Um retrato em processo}

A repetição,em fotogramas, dos grandes painéis, sugere ao leitor um autoretrato em processo, onde a passagem do tempo e as transformações do objeto em decorrência do mesmo são explicitados pela sua configuração.A forma com que a obra foi concebida, em grandes dimensões, obriga o leitor, no ato de leitura, a percorrer um espaço dentro de um tempo, para que os olhos possam "varrer" toda a superfície dos painéis. Essa 
experiência estética, fornece ao leitor a consciência de que o tempo está passando não só para o objeto retratado (a própria artista) e dado em fotogramas, mas também o tempo dele (leitor) ao deslocar-se no espaço.

No primeiro painel, a repetição da fotógrafa deitada em pose intercala-se com o cenário da foto sem o modelo. Uma ausência que pode indiciar uma dificuldade dessa auto-representação, ou uma hesitação da afirmação de uma imagem, pré-enunciando uma transformação.

Outra questão explícita na estrutura da imagem construída por Costi, é a representação do pela sucessão de fotos, em pose imóvel, que pode indiciar a impossibilidade humana diante da passagem do tempo.

O fato de Rochelli Costi compor sua obra com fragmentos das pinturas que os alunos realizaram dela enquanto posava, traz à baila uma reflexão sobre o espelho (como vejo e como sou visto). Ao se auto-retratar, colocando a câmera fotográfica no tripé enquanto posava, a fotógrafa expôs o olhar da alteridade sobre si, como é vista pelos que a vêem, naquele momento. Entretanto, quando compõe os fragmentos dos painéis, a escolha, o modo como organizou, expõe o seu olhar sobre si.

Além disso, oferece também, uma atualização crítica da representação da mulher dentro da tradição ocidental. $O$ nu feminino, construído e desconstruído, com sua historicidade, está presente na obra de Costi.

A nudez para um auto-retrato sugere uma super exposição de si mesma. Contudo, ao se apresentar com os olhos fechados, Rochelli Costi enuncia um enigma. Costi expõe sua superfície, aquela vista pelos outros, que pode ser fotografada, pintada, recortada, que se dá a ver, mas a essência está reservada, sob os olhos cerrados.

O título da obra orienta a leitura indiciando a passagem do tempo 50 horas. E, Auto-retrato Roubado, propõe uma ambigüidade: roubado, porque expõe fragmentos das pinturas dos alunos?; por ela, a fotógrafa ter se colocado, ao mesmo tempo, com objeto e artista, furtando a experiência que era dos alunos, ao posicionar sua câmera?; ou, o que foi roubado... foi o tempo, imóvel por cinqüenta horas?

\section{A espiral hermenêutica}

A arte para ser arte deve travar um diálogo com o seu tempo. Para ser arte, atravessa o tempo, e adquire um caráter atemporal, podendo promover diálogos com outros presentes. As múltiplas possibilidades que o leitor tem de criar trajetos de leitura salientam a ambigüidade existente em uma obra 
artística. A arte se apresenta como feixe de possibilidades, o movimento da leitura é centrífugo (JOUVE,2002), ou seja uma hermenêutica que não busca um conteúdo cristalizado no texto, um centro. Apreciamos a imagem utilizada por Zilberman (1989,p.73) para representar esse movimento centrífugo: "a hermenêutica troca o círculo pela espiral das infinitas interpretações”.

\section{Bibliografia}

BOSI, Alfredo. Reflexões sobre a Arte. São Paulo: Editora Ática. 2002.

Letras, 1995.

. Fenomenologia do Olhar. In NOVAIS, A. (org) O Olhar. São Paulo: Companhia das

CHARTIER, Roger. A Aventura do Livro: do leitor ao navegador - Conversações com Jean Lebrun. São Paulo: Editora UNESP,1998.

FERRARA, Lucrécia D`Aléssio. A Estratégia dos Signos. São Paulo: Perspectiva,1986.

Leitura sem Palavras.São Paulo: Editora Ática,2000.

ISER, Wolfgang. A interação do texto com o leitor. In: LIMA, Luiz Costa (org). A Literatura e o Leitor. Rio de Janeiro: Paz e Terra,1979.p 83 - 132. . O Ato de Leitura. São Paulo: 34, 1996.

JAUSS, Hans Robert. A História da Literatura como Provocação à Teoria Literária. São Paulo: Ática, 1994.

JAUSS, Hans Robert. Limites e Tarefas de uma Hermenêutica Literária. In Poetik und Hermeneutik vol.IX. Monique, 1980.

JOLY, Martine. Introdução à Análise da Imagem. Campinas: Papirus Editora,1999.

JOUVE, Vicent. A Leitura. São Paulo: Editora UNESP,2002.

MITCHELL, W. J. T. (org). The Language of Images. Chicago: The University of Chicago Press, 1980.

. Iconology: Image, Text, Ideology. Chicago: The University of Chicago Press, 1986.

NOVAIS, Adauto. (org) O Olhar. São Paulo: Companhia das Letras, 1995.

PAREYSON, Luigi. Os Problemas da Estética. São Paulo: Martins Fontes,1997.

PLAZA, Júlio. Tradução Intersemiótica. São Paulo: Perspectiva, 1987.

ZIBERMN, Regina. Estética da Recepşão e História da Literatura. São Paulo:Ática,1989. 

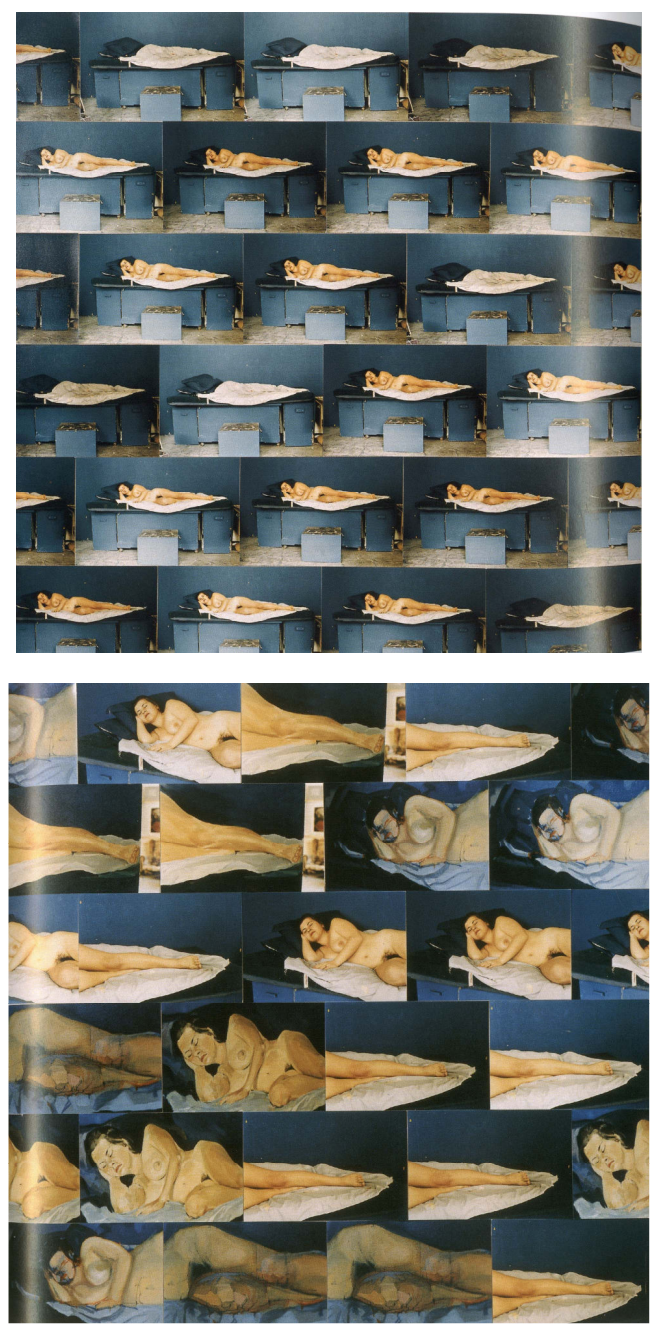

Rochelli Costi

50 horas: Auto-Retrato Roubado 1992

Cópias cromógenas 59,7x 59,7cm 